\title{
ЛЮДВИГ СелИМСки
}

\section{ЗА ПРОИЗХОДА НА ПЕТНАЙСЕТ БЪЛГАРСКИ ДУМИ}

CoBIss: 1.01

\begin{abstract}
K izvoru petnajstih bolgarskih besed
V članku se analizira 8 besed, pretežno narečnih, zvečine podedovanih, ki so bile zavoljo specifičnih glasovnih sprememb, besedotvornih posebnosti ali pisnih deformacij napačno interpretirane v BES (Bolgarskem etimološkem slovarju) ali štete za nejasne; 7 drugih besed pa je semantičnih ali besedotvornih arhaizmov, ki v BES niso bile podvržene analizi. Ključne besede: pisne deformacije, disimilacija, izposoja, poenostavitev
\end{abstract}

\section{On the origin of fifteen Bulgarian words}

This article analyzes eight words, mainly dialect lexemes and mostly inherited, that due to specific sound changes, word-formation features, or graphical deformations have been wrongly analyzed in BED (the Bulgarian Etymological Dictionary) or considered obscure. Seven other words that are semantic or word-building archaisms that were not included for analysis in BED have been studied.

Keywords: graphic deformation, dissimilation, borrowing, simplification

0 В статията се разглежда произходът, словообразувателният строеж и първоначалното значение на 15 български думи. Относно 6 от тях се дискутира по тези проблеми с БЕР, при 1 - със С. Илчев, а 1 е счетена в БЕР за неясна. Останалите 7 от интересуващите ни тук думи не са били анализирани в БЕР. Думите се анализират по азбучния им ред.

1 Влашко ножче - от влах или от ула̀к? Определението влашки в съчетание с ножче (влашко ножче) се привежда сред производните от етнонима влах в дефиницията на значението на „влаша̀к 'несгъваем нож с ножница, влашко ножче’ (Вакарел, Ихтиманско)“ (БЕР 1: 164, под влах). Словосъчетанието „влашко ножче“ се среща в песенния фолклор. Инициалното в- тук е поради свръхстарателност. Тук влашки няма нищо общо с етнонима влах, нито с

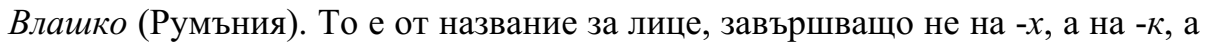
започващо не с в-, а с гласната $y$-. Това название е ула̀к (в мн. ч. ула̀uи), за-

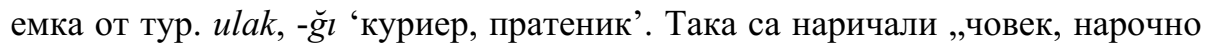
изпратен нейде с писмо или за друго нещо; саия“ (Геров 5: 431). То е заето и в румънски (olac) и в други балкански езици (БЕР 8: 628, под ула̀к). Освен паралелната форма ула̀ка, умалителното ула̀че и прилагателното ула̀шки, $\mathrm{H}$. Геров привежда и словосъчетанието улашки кон, съответстващо на рум. cal de olac, а също така и фрагмент от народна песен с прилагателното ула̀шки: 
„Бальо въз Янка отиде,/ Че извади ножче улашко,/ Улашко и касапско,/ У клето се сърце рани“ (Геров 5: 431).

Отбелязваме го в Свищовския дамаскин в словосъчетанието „ола́ците цареви“ (Милетич 1923: 473), на което съответства „посла́нници ца́ревы“ в Троянския дамаскин (с. 270 [вътр. пагинация]) и Тихонравовския дамаскин (с. 1396, вътр. паг.).

2 Вощанин ‘воин’. Според С. Илчев (1969: 116) в основата на ФИ (фамилно име) Вощански е залегнало ЛИ *Воща̀н, което - не съвсем уверено - той извежда „от диал. *воскян 'восъчен' - във връзка с употребата на восъка в черква за свещи (?)“. Н. Ковачев (1995) не отбелязва лично име * Вощан. А сред подобните на предполагаемото * Вощзан „от диал. *воскян 'восъчен'“ с алтернация $c \kappa \sim щ$ са отбелязани во̀щен, вощенка, вощеница, вощина и др. (БЕР 1: 176-177), но сред тях няма съществително *вощан/*вощяя. По всяка вероятност ФИ Вощзански се базира върху прозвище от название като отбелязаното в Свищовския дамаскин воща́нинь 'боец, воин, войник', което съответства на названия за 'воин' в паралелни текстове от други

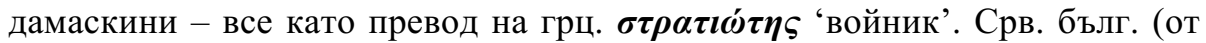
Свищовския дамаскин) „и кажеше о́ти сьм воща́нинь Ісусу Назара́нину“

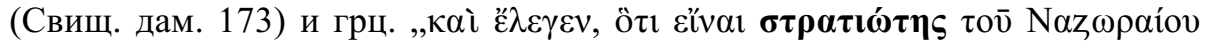

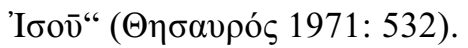

Л. Милетич, който публикува Свищовския дамаскин, помества думата вощза́нинь в списък от „По-редки български думи““ в паметника, като привежда няколко употреби (Милетич 1923: 60). А според нас бълг. воща́нинь (по-рядко вощзанинь) е заето от румънски език. То съответства на рум. oşteàn 'войник, боец; военен', образувано с наст. -eàn от òşti, форма за мн. ч. на думата oàste (остар.) 'военна служба; войска, армия; война, сражение, битка', извеждана от лат. hostem < hostis 'чужд’, а напоследък се смята „от трако-илир. произход“ (Vinereanu 2009: 587). На българска почва е развило протетично в-, може би не без асоциация със синонимното воин.

3 „Пашайши нареч. ‘безгрижно, напълно свободно’ (Тиквеш). - Може би от основата с паша (вж.), срв. тур. paşasi ‘с качествата на паша' [...]“ (БЕР 5: 115). По-добре „от основата на паша“, отколкото „от основата с паша“. А пашайши не можем да приемем за наречие с наст. -si поради очевидната фонетична разлика между изгласното -йши на загадъчната дума и крайното -si на така предполаганата изходна форма. Най- вероятно е зад привидно еднословното пашайши да се крие изафетното съчетание *паша̀ ишй, в което освен namà (тур. paşa) има още две морфеми: лексикална (коренна) *uш (от тур. iş 'работа') и служебна, с морфосинтактична функция на изафет - крайното - $и$ (от тур. - $i$ ). Предполагаемото изходно турско словосъчетание е *paşa işi 'работа/грижа на паша', подобно по строеж и преносно 
значение на тур. с̧осиk işi 'детска (много лесна/незначителна) работа' (по АкТБР 2009: 294).

4 См’ồнвам гл. нсв., см’ồна $c$. 'удрям до смазване' се среща на много места в Смолянско и Ардинско (Стойчев 1983: 340). То не е отбелязано на азбучно място в БЕР 7, а липсва и сред производните от основното мәेна 'отделям влакната от паздера на лен и коноп’ и др., от псл. *męti, mbno (БЕР 4: 396397). В него забележително е запазването на мекостта на съгласната пред широкото родопско $\grave{\hat{\boldsymbol{o}}}$, явяващо се застъпник на коренната предна гласна (от псл. $\left.{ }^{*} e \sim *_{b}\right)$, което е характерно за родопските говори, срв. см'оे̀а и пол. zmiqć 'смачкам, измачкам'.

5 Со̀̀стук и състук ‘водопад’. Со̀̀стук ‘водопад’ (Брезе, Смолянско) се извежда „от соेскук сыщо (вж.), с дисимилация $\kappa-\kappa>m-\kappa$. Срв. състук, ско̀куm“ (БЕР 7: 358). Но формация ско̀кут липсва на азбучно място. И паралелното състук ‘водопад’ (Лясково, См) се извежда „от първоначално сьेскок също, съставено от $c b-[. .$.$] и скок 'водопад' [...] и дисимилация \kappa-\kappa>m-\kappa$, срв. соे̀кук 'водопад’

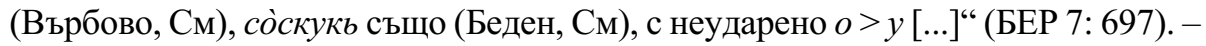
Според нас анализът на соेстук/с⿱宀с⿰тук е неприемлив. Промяна в корена на този хидронимен термин е претърпяла само гласната $o$, която в неакцентирана позиция се редуцира: $o>y$. Предполагаемата „дисимилация $\kappa-\kappa>m-\kappa$ “ би била уникална, а въобще не е наложително да се реконструира формация с

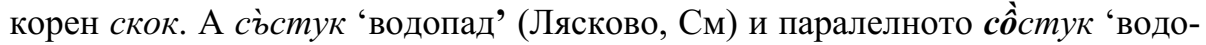
пад’ (Брезе, См), с широко $\hat{o}(<o)$, си представяме като варианти на съществително *cъ-сток (от глагол *cъ-стека), застъпващо диал. псл. *sb-sъtokb (: *sb-sbtekti), подобно на по-простото сток (: стека̀ [ce]), от псл. *sъtokъ (: *sbtekti) за 'място, където две или повече реки се сливат, стичат в една; сток' (Геров 5: 261). Участващата в повторната префиксация представка * $s z$ на глагола *sъsbtekti, мотивиращ съществителното *sъsъtokb, се различава не само формално - по вокализацията на *ъ в силна позиция $\left({ }^{*} s b->c b-/ /\right.$

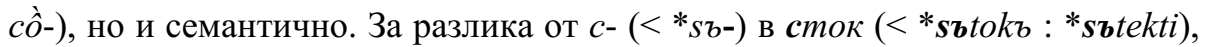
означаваща 'събиране/стичане на водите на два или повече потока/реки в

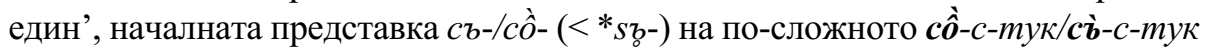
(<*sb-sb-tokb) 'водопад’ означава 'отделяне (на водния поток) от едно земно ниво и падане в друго, по-ниско’. Префиксът $c b^{-}\left(<*_{s \boldsymbol{b}}\right)$ в диалектния хидронимен термин съответства на стб. предлог съ за 'отделяне с посока отгоре надолу’. А в съвременния книжовен език няма „семантично съответствие между предлога $c$ и префикса $c$-“, „глаголите с представка $c$ - са обикновено стари образувания, в които представката е споена здраво с корена формално и семантично“ - тя днес не е словообразувателно активна (Спасова-Михайлова 1978: 203-204). Относно така предполаганата семантика на инициалната представка срв. родоп. са-сурккам (ca) 'свличам (се)', съ-влека (с вокализирана 
ерова гласна), с-влачище, с-валям, $\boldsymbol{c}$-лизам, $\boldsymbol{c}$-мъквам, $\boldsymbol{c}$-немам, $\boldsymbol{c}$-пада 'слиза, смъква се, спуска се' (Селимски 1996: 35-36; 2016: 68).

6 * Спа̀ждам се достоверно ли е по форма, или не? Глагол спа̀ждам се 'влизаме един в друг; спояваме се, спаяме се', с употреба в изреч. Кьунковете са спаждат един с друг. МСб. XVI-XVII. 406, както и отглаголно съществително спаждане „с. сp. от спа̀ждам се. Спояване“, отбелязва Т. Панчев (1908: 295296). Този глагол не е включен за анализ в БЕР 7. От синонимните в дефиницията на значението му спояваме се, спаяме се може да се предполага, че и в загадъчното спажадам се имаме префикс $c$-. Според нас обликът спаждам

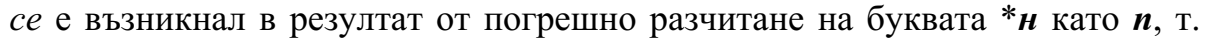
е. вместо снаждам се, каквото Т. Панчев не отбелязва на отделно азбучно място. Но все пак в подобен контекст се отбелязва и дума, която смятаме за сродна с интересуващата ни тук. Това е на̀душка „мястото, дето две неща се спаждат, се съединяват едно с друго; частите, с които се спаждат две неща. Нъ кьу̀нкъ на̀душката. Търново, МСб. XVI-XVII. 406“ (Панчев 1908: 220). И в приведената дефиниция на семантиката се явява същото „се спаждат“ вместо „се снаждат“. А на̀душка е образувано с наст. -ушка за отглаголни названия на действия, като диал. съмну̀ика 'съмване, съмнало', разг. почерпу̀шка 'почерпка' и др. То се базира на глагола на̀дам или на̀дя 'снаждам, наставям', от който имаме и причастие/прилагателно на̀ден 'продължен чрез прибавяне на ново парче’ и др. производни, сред които и на̀душка, сна̀дя и търсеното в нашия анализ сна̀ждам 'наставям нещо; удължавам нещо чрез зашиване; съединявам две неща' (БЕР 4: 471-472), погрешно представено у Т. Панчев като недостоверното *cnàждам (ce), а неправилно и като възвратен глагол - не „спояваме се“, а спояват се, т.е. биват споявани, а всъщност: кюнковете биват снаждани или кюнковете ги снаждаме.

7 „Становище 'гледище, мнение, гледна точка', 'място или сграда за престой' (РРОДД). - Срхр. ста̀новйште 'гледище, позиция', словаш. stanovište 'място', пол. рядко stanowiszcze 'гледище'. - Произв. от *stānъ (вж. стан), с наст. -av-išče“ (БЕР 7: 431). При изброяването на съответствия в другите езици са предпочетени и „пол. рядко stanowiszcze“ и ,словаш. stanovište “място“", а е пренебрегнато чеш. stanoviště, което е най-важното в случая. Защото дори и да е на домашна почва образувана думата становище за означаване на 'място или сграда за престой', не може да се предполага домашно потекло на cmaновище като 'гледище, мнение, гледна точка'. С второто значение то е чешка заемка, въведена от А. Теодоров-Балан (Иванчев 1983: 321; 1988: 209). В предговора към книгата си „Български залиси“ в порядъка на творческа равносметка и не без чувство на законна гордост А. Теодоров-Балан пише, че „българският книжевен език си служи днес с няколко десетки думи строени“ от негова „рька изкарани и пуснати на пазар“ (Теодоров-Балан 1956: 4). Тук 
той привежда за илюстрация 24 думи и изрази, сред които е и становище. А подробен анализ на тази дума публикува по-рано. Според Балан, „да беше думата становище произведена у нас от стан, като място, дето се станува (дето се стои на лагер), тя щеше да гласи станище [...]. Българската железнична управа е нарекла добре български станище едно място в Русе [...]. А формата становище, усвоена еднъж от чешки, бихме запазвали с изгода за значение, дето не е работа за 'стояне' или 'застаяне', но повече за 'поставяне’ (stanoviti, stellen)“ (Теодоров-Балан 1927: 164-165; 1956: 176-180).

8 „Ствар остар. ‘предмет, вещ, нещо, твар', ‘твар, живо същество’ (Ем. Васкидович). - Поствербално образуване от стварам (вж.)“ (БЕР 7: 440). - Най-вероятно е то да е заемка - срхр. ства̂p. Относно езика на Ем. Васкидович това не бива да ни учудва. Срв. подчертаните два сърбизма в следния фрагмент от негово изречение: „гол се вратих, без да посвоя нито ботка от сиромашка кръв“" (по РБЛ 1: 202). А относно интересуващата ни дума отдавна е изказвано мнение, че е хърватизъм в банатския говор (Милетич 1900: 480).

9 Стъга (у Геров стжга) „въже, с което порожат добитък; порожница, порожь, пороже“ (Геров 5: 281), е интересна дума, която липсва в БЕР 7. Архаичното, както изтъква и С. Младенов, „с/тжга обл. стар. 'въже...'; кор. в др. отгл. степ. ст Аг- в стыгам“ (Младенов 1941: 616), сродно със стб. глагол въстагмжти ‘стянуть, обуздать’ (SJS I: 342), то застыпва псл. *sb-tog-a, от което е и рус. стуга 'тясна лента' (Vasmer 3: 33), словаш. stuha 'лента, панделка, ширит' (Králik 2016: 563), чеш. stuha (и stouha) ‘панделка, кордела, лента' (Machek 1968: 590), долнолуж. stuga ,älter 'Senkel, Schnürsenkel, Riemen'“ (Schuster-Šewc 18: 1370). В някои славянски езици се явяват други производни, като словен. stộgla 'ремъче за завързване на чехли', разширено с наст. -la (Bezlaj 3: 319), каквото е и приведеното у В. Махек словаш. stuhl'a. А за стч. vztúha 'първонач. каишка, с която се е пристягала обувката към крака’ (Machek 590) и пол. wstega 'лента’ (и умалит. wstażka 'панделка'), правилната реконструкция е *vъz-toga от глагола *vъz-tegneti (Mańczak 2017: 363).

10 „Стърна (да се), -еш, -нал се, гл. възвр. свър. (?) Враг ти се стръну̀ло, да би ти се! Клетва. МСб. ХХІ. Трънско 60“ (Панчев 1908: 300). - Липсва на азбучно място в БЕР 8. На Т. Панчев този глагол не е бил ясен откъм словообразувателен строеж и лексикално значение. Обръщали сме вече внимание върху него, между другото, при анализа на бълг. диал. сутрущцвам 'убивам' (Selimski 1998: 235-236; Селимски 2016: 81-82). Там се привеждат клетви, като Дано го болест тръти!...; Бабник те трътил! Те са от същата основа (псл. *trotiti), от която много производни привежда И. Дуриданов, включително и трътна, но като св. в. срещу тръткам 'надвивам, събарям 
някого’ (Дуриданов 1983: 61). А интересуващото ни тук стърна се смятаме застьпник на префиксно-суфиксна формация като псл. *sbtrqtneti, с представка ${ }^{*} s b$ - и наст. *-nQ- за св. в. от trotiti, с формиране на вторично сричково -ръ-/-ър-, срв. *трътя, трътна, трътнуам 'повалям' (БЕР 8: 337) и търтя 'поваля', потъртя, потрътвам 'повалям' (БЕР 8: 570) и опростяване на консонантната група -ртн- (> -рн-), както при загъртам диал. 'загръщам', пригъртам диал. и загърна, пригърна (БЕР 1: 290, s.v. *грът-).

11 Тий 'това'. Тази рядка диалектна форма не е поместена за анализ в БЕР 8. Тя е подобна на местоимението за ср. р. ед. ч. вин. п. ний 'него' от банатския и павликянския говор, съответстващо точно на диал. (Шуменско) ней (от псл. *nbjb), но с промяна на акцентираното $\grave{e}$ в нова фонема $\grave{u}$, различна от етимологичното $\grave{u}$ (Селимски 1974; 2006: 44-45; 2016: 110). Тя е подобна също така и на местоименната форма сий (Селимски 2015: 311-312).

Новата фонема $\grave{u}$ (на мястото на $\grave{e}$ ) се различава от по-ниската $u$, явяваща се застъпник на етимологичното $u$, което съвпада с рефлекса на $b l$ в говора, както в украински. Става дума за павликянския говор, а интересуващото ни тий 'това' е от гр. Раковски (Пловдивско). Намираме го също така и в текст на основата на този говор от средата на XIX в., чиито съставители са католически свещеници, родом от същото селище. Ето го в контекст: „Draghi moj Spassitel, zaràd tàzi tvója prisvèta pàhà prejemì dnès tij mojè nevòlno tèlo, $\mathrm{i}$ dai mu pokòra kakvà ti iskasc" (Arabagiski - Iakovsky 1844: 140).

За отбелязване тук е важното обстоятелство, че гласната $\grave{u}$ в местоимението тий, съвпадаща с гласната в споменаваните ний и сий, трябва да е обобщена от тези най-близки семантично и морфологично местоимения. Тя в тий не може да бъде непосредствен континуант на твърдата ерова гласна на псл. *tъjb.

Вероятно по същия начин се е формирало и родопското - от Елховец (Смолянско) - ,тий и тий нарч. Тъй и тъй““ (БДиал 2: 280).

12 Трыेна 'тръпна', Кракъ ми транй, диалектно (Врачанско) (БДиал 9: 330), липсващо в БЕР 8. Подобно на стб. оутрънжти, оутръпати (SJS IV: 715), то е с опростена структура на сричката (*tbrp- $n->m p z-H-)$, както в сх. $\boldsymbol{m p ́} \boldsymbol{\mu} y$ -

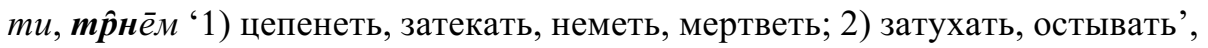
словен. otrpnuti 'окочанясам', словаш. trnút', -niem '1. замирам, вцепенявам се; 2. безпокоя се, вълнувам се', покрай варианта от XVII в. tŕpnut', -nem '1. тръпна, изтрьпвам, вцепенявам се (за крак, ръка); 2. вцепенявам се, изтрьпвам, замирам (от страх)', чеш. trnouti '1. трьпна, вцепенявам се; 2. замирам, вдървявам се, вкаменявам се (от страх)', ztrnouti, ustrnouti, диал. (лаш.) trpnut', пол. tarnqć 'изтрьпвам, вдървявам се, вцепенявам се', рус. терпнуть, укр. потерпнути - все от псл. *tьrp-no-ti (Machek 1968: 652; Králik 2015: 628). 
13 „Туто̀ве “словаци’ в текст: Женските прасета се „икупѐват”...Това вършат ветеринарните лекари и „туто̀ве” (словаци) от съседните села... (Банат, СбНУ 51, 62). - Неясно“ (БЕР 8: 463). Отнася се за име с окончание за мн. ч. -ове, следователно едносрично от м. р. Ако предвидим и редукция в коренната гласна на едносричната основа, т.е., че туто̀ве може да бъде вм. *тото̀ве, ясно е, че става дума за банатското етнично название тот, за което С. Стойков (1968: 234) пише: „остар. (унг.) Словак. То̀твете съте са уд на̀шта вѐра [т.е., католици: ЛС]. Туто̀вете шкупѐват свин'ъте“. Стойков привежда и произв. „то̀тск’u, -ска прил. остар. Словашки. Тоттск'и йъзйк“ (с. 234). То е от унг. Toth 'словак', което от XVII в. означава и 'сърбин' (Šimunović 1995: 380). А според П. Скок унг. Tót се отнася ,и за хърватите между р. Сава и Драва“" (Skok 3: 485). То е заето и в румънски: tot, toți (обл., остар.) 'словак', от унг. tót (DLRM 1958: 870). Срв. и рум. ФИ „Tot: ung. tót 'slovac'. Cf. Tăutu“" (Iordan 1983: 459), „Tăut(u): ung. tót 'slav; slovac'“ (Iordan 1983: 446). Относно сематичния развой от етноним към занятие или обществено положение срв. грък 'търговец', циицарин 'търговец', а най-вече: словаш. valach '1. пастир, овчар; 2. кон', чеш. Valach 'румънец', a valach 'пастир (в Изт. Моравия); скопен жребец’. Както пише по-нататък Й. Рейзек, „румънските Valaši стигнали при колонизацията на Карпатите чак до Изт. Моравия (оттук моравски валаши) и запознали местното население с кастрацията на жребците, оттук названието за скопен жребец“' (Rejzek 2001: 697).

14 „Търъпъна̀ ж. 'голям дървен съд, приличащ на корито, който се използва при гроздобер' (Желю войвода, Сливенско). - От тарапана̀ (вж. mapanхана)“ (БЕР 8: 575). - При това тълкуване е пренебрегната семантиката няма никаква смислова връзка между 'корито за гроздобер' и 'работилница за сечене на пари'. Най-вероятно е да имаме пореден случай на „графична деформация“ на изследваната дума - погрешна замяна на началното *u- с m-. А въпросната дума е шарапана̀ 'голямо дървено корито, в което берат грозде’ (БДиал 3: 193), шъръпъньे ‘кораб за грозде’ (БДиал 5: 147), от шараnхана̀ (у Геров 5: 574) 'корито на кола за прекарване грозде', от ар.-пер.-тур. şaraphane ‘винарска изба' (Георгиев 1978; Селимски 1978; 2016: 10-13).

15 Углу̀тка 'недоразвито дете' и сродни. В БЕР 8 се анализират няколко производни от люде или от забравеното *люд (от псл. *l'udъ) (БЕР 8: 634-634, под улюдвам). Но и в този том на БЕР, въпреки старанието за пълнота на изследвания речников материал, са останали незабелязани някои словообразувателни и семантични архаизми, за които се намират съответствия в други славянски езици. За такова смятаме родопското углу̀тка 'недоразвито [...] дете' (Стойчев 1983: 344), анализирано като субстантивация на прилагателно *одл'yден, противоположно по значение на вл'у̀дан 'възпитан', а съответстващо на словаш. odludný 'саможив', пол. odludny 'намиращ се, живеещ 
далече от хората, странящ от хората' и укр. відлюдний 'необщителен, уединен’. Субстантивацията е осъществена с наст. -ек/-к-, която се среща с умалителна или сингулативна функция в сродната родопска формация л'утко̀ве

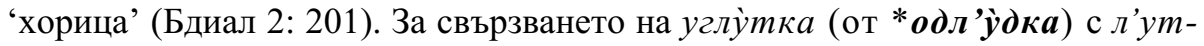
ко̀ве не пречи нито частичната дисимилация дл > гл, нито затвърдяването на $л^{\prime}>$ л (вж. БЕР 3: 486). Така углу̀тка се очертава като точно съответствие на пол. odludek и укр. відлюдок 'необщителен човек, саможивец' - също от субстантивация на прилагателни (пол. odludny и укр. відлюдний), срв. и луж. wotliudk 'eremita, Einsiedler'. Срв. също пол. niedoludek 'който не умее да съжителства с хората', укр. недо́люд(ок) 'изверг, изрод', чеш. nelida 'безчувствен човек, човеконенавистник', рус. и укр. ублюдок 'недоразвит, за нищо негоден човек, с низки инстинкти; изрод’. Родопската форма от ж. p. на - $a$ е резултат от обобщаване на род.-вин. форма (от изрази като „остави го този *одл'уेдка“). А самото родопско лютко̀ве, с уж „неясно образуване“ (БЕР 3: 584), кореспондира точно с чеш. диал. lidkové, l'udkové, словаш. l’udkovia, пол. диал. ludkowie, белорус. диал. л'утко́в'е, людкове, длж. ludki, lutki (Schuster-Šewc 12: 870-871, под lutki ${ }^{2}$ ), укр. людки, пол. ludek и се извежда от псл. *l'udъkъ (от основа l'udb и суф. -ъкъ с умалителна или сингулативна функция (Селимски 1996: 40-41; 2016: 73-74).

Така углу̀тка и л'утко̀ве от родопските говори - несьмнено архаична периферия, - ведно с приведените (и други, неспоменати тук) сродни формации идват в подкрепа на реконструкцията на псл. *otъl'udъkъ (ЭССЯ 37: 144-145), в основателността на която като че ли се съмнява А. Банковски, смятайки пол. „odludek 'mizantrop' 1564, sztuczny nowotwór Mączyńskiego [...] bez wzorów obcych" (Bańkowski 2: 378).

Надяваме се, че не само с предложените поправки на известни вече тълкувания, но и насочвайки вниманието към някои необхванати за анализ в БЕР или/и ЭССЯ български диалектни думи, сме допринесли между другото и за утвърждаването на мнението за архаичния характер на родопските говори и за тяхното огромно значение за възстановяването на българската част на праславянския речник.

\section{ЛИТЕРАТУРА И СЫКРАЩЕНИЯ}

АкТБР 2009 = Академичен турско-български речник, ред. И. Добрев, София: РИВА, 2009.

БДиал 1-10 = Българска диалектология: проучвания и материали I-X, София: БАН, 19621981.

БEP 1- 8- = Български етимологичен речник, София: Проф. М. Дринов, 1971-2017-.

Георгиев 1978 = Владимир Георгиев, Относно произхода на диалектното съществително шарапана, Български език 28 (1978), бр. 1, 52-53.

Геров 1-5 = Найден Геров, Речник на българския език, фототипно изд., София: Български писател, 1975-1978. 
Дуриданов 1983 = Етимологични бележки към бълг. тръшвам, тръшна, тръшкам, Език и лиmература 38 (1983), бр. 2, 59-64.

Эсся 37 = Этимологический словарь славянских языков: праславянский лексический фонд 37, ред. А. Ф. Журавлев, Москва: Наука, 2011

Иванчев 1983 = Светомир Иванчев, Александър Теодоров-Балан като проводник на чешкото влияние в българския език, Slavia 52 (1983), с̌. 3-4, 317-321 (= Иванчев 1988: 203-209).

Иванчев 1988 = Светомир Иванчев, Българският език - класически и екзотичен, София: Нар. просвета, 1988.

Илчев 1969 = Стефан Илчев, Речник на личните и фамилни имена у българите, София: БАН, 1969.

Ковачев 1995 = Николай Ковачев, Честотно-етимологичен речник на личните имена в съвременната българска антропонимия, Велико Търново: ПИК, 1995.

Милетич 1900 = Любомир Милетич, Книжнината и езикът на банатските българи, Сборник за народни умотворения, наука и книжнина 16-17 (1900), София: Министерство на народното просвещение, 339-482.

Милетич 1923 = Любомир Милетич, Свищовски дамаскин. Новобългарски паметник от XVIII век. Български старини VII (1923), София: БАН.

Младенов 1941 = Стефан Младенов, Етимологически и правописен речник на българския книжовен език, София: Христо Г. Данов, 1941.

Панчев 1908 = Тодор Панчев, Допълнение на българския речник от Н. Геров, събрал, наредил и изтълкувал Т. Панчев, Пловдив: Печ. „Труд“, 1908.

РБЛ 1 = Речник на българската литераура 1: А-Д, София: БАН, 1976.

Селимски 1974 = Людвиг Селимски, Българската диалектна фонемна промяна $\grave{e}>\grave{u}$, в: $B$ nамет на професор Стойко Стойков (1912-1969): езиковедски изследвания, София: БАН, 1974, $183-187$.

Селимски 1978 = Людвиг Селимски, Думата шарапана̀ не е тракийска, а арабско-персийска, Език и литература 33 (1978), бр. 1, 106-107 (= Селимски 2016: 10-13).

Селимски 1996 = Людвиг Селимски, Значението на родопските говори за възстановяването на праславянския речник, Rocznik Slawistyczny 50 (1996), cz. 1, 31-44 (=Селимски 2016: 62-75).

Селимски 2006 = Людвиг Селимски, Етимологични поправки, уточнения и допълнения, в: Националният език в условията на чужди влияния и глобализация. Научна конференция, посветена на 125-годишнината от рождението на акад. Стефан Младенов (София, 28-29 юни 2005), София: Изд. на СУ в България, 2006, 40-46 (= Селимски 2016: 102-111).

Селимски 2015 = Людвиг Селимски, Об этимологии двадцати слов: дополнения и исправления к «Болгарскому этимологическому словарю», в: Памяти академика Олега Николаевича Трубачева к восьмидесятилетию со дня рождения (23.10.1930 - 9.03.2002) = Труды Инст. русск. языка им. В. В. Виноградова IV: этимология, Москва: Изд. «Вест-Консалтинг», 2015, 303-322.

Селимски 2016 = Людвиг Селимски, Етюди по етимология и ономастика: studia $z$ etymologii $i$ onomastyki, Велико Търново: УИ „Св. св. Кирил и Методий“, 2016.

Спасова-Михайлова 1978 = Сийка Спасова-Михайлова, Семантични сыпоставки между предложната и префиксалната система на славянските езици, Славянска филология 15 (1978), София: БАН, 1978, 195-206.

Стойков 1968 = Стойко Стойков, Лексиката на банатския говор, София: БАН, 1968 (ТБД 4).

Стойчев 1983 = Тодор Стойчев, Родопски речник: второ допълнение, Родопски сборник 5 (1983), ред. Х. Христов и др., София: БАН, 287-353.

Теодоров-Балан 1927 = Алексанндър Теодоров-Балан, Думотворба: гледище и становище, Родна реч (Казанльк) I (1927), 163-168 (= Теодоров-Балан 1956: 176-180).

Теодоров-Балан 1956 = Алексанндър Теодоров-Балан, Български залиси с език, книжнина и общество. София: Наука и изкуство, 1956.

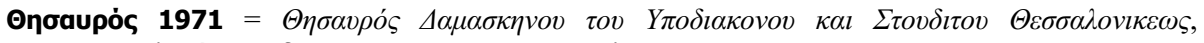

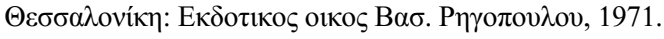


Arabagiski - Iakovsky 1844 = Petrus Arabagiski - Iakobus Iakovsky, Nauka kristianska za kristianete od Filibeliskata darxiava, Rim: Propaganda fide, 1844.

Bańkowski 2 = Andrzej Bańkowski, Etymologiczny stownik języka polskiego, Warszawa: PWN, 2000.

Bezlaj 3 = France Bezlaj, Etimološki slovar slovenskega jezika 3: $P-S$, dopolnila in uredila M. Snoj M. Furlan. Ljubljana: Mladinska knjiga, 1995.

DLRM = Dicționarul limbii romîne moderne, București: Ed. Academiei RPR, 1958.

Iordan 1983 = Iorgu Iordan, Dicționar al numelor de familie româneşti, Bucureşti: Editura Ştienţifică şi Enciclopedică, 1983.

Králik 2015 = Lubor Králik, Stručný etymologický slovník slovenčiny, Bratislava: VEDA, 2015.

Machek 1968 = Václav Machek, Etymologický slovnik jazyka českého, Praha: ČSAV, 21968.

Mańczak 2017 = Witold Mańczak, Polski stownik etymologiczny, wyd. elektr. pdf, 2017.

Rejzek 2001 = Jiří Rejzek, Český etymologický slovnik, Voznice: Leda, 2001.

Schuster-Šewc 12, 18 = Heinz Schuster-Šewc, Historisch-etymologisches Wörterbuch der ober- und niedersorbischen Sprache 12, 18, Bautzen: VEB Domowina-Verlag, 1983, 1986.

Selimski 1998 = Ludwig Selimski, Z prasłowiańskiego dziedzictwa leksykalnego $\mathrm{w}$ bułgarskich gwarach ludowych, w: Prastowiańszczyzna i jej rozpad, red. J. Rusek - W. Boryś, Warszawa: Energeia, 1988, 231-237 (= Селимски 2016: 75-82).

SJS I-IV = Slovník jazyka staroslověnského = Lexicon linguae Palaeoslovenicae I-IV, red. J. Kurz Z. Hauptová, Praha: Akademie věd, 1966-1994.

Skok 3 = Petar Skok, Etimologijski rječnik hrvatskoga ili srpskoga jezika 3: poni ${ }^{2}-\check{Z}$, Zagreb: JAZU, 1973.

Šimunović 1995 = Petar Šimunović, Hrvatska prezimena: podrijetlo, značenje, rasprostranjenost, Zagreb: Golden Marketing, 1995.

Vasmer 3 = Max Vasmer, Russisches etymologisches Wörterbuch 3: Sta- , Heidelberg: Carl Winter Universitätsverlag, 1958.

\section{PovzeteK}

\section{K izvoru petnajstih bolgarskih besed}

V zvezi s 6 besedami (št. 1, 2, 3, 5, 7, 8, 14) se članek razhaja z BES (Bolgarskim etimološkim slovarjem) oziroma št. $2 \mathrm{~s}$ S. Ilčevim, medtem ko je št. 13 za BES 'nejasna'. Preostalih 7 besed (št. 4, 6, 9-12,15) pa v BES ni bilo analiziranih.

Avtor šteje za izposojo: 1. osnovo za vlaški (ulàk 'kurir', tur. ulak); 2. voščanin 'vojak' (rom. oşteàn); 3. pašajši ‘brezskrbno' (tur. paşa işi 'paševa skrb'); 7. stanovište 'stališče' (iz češ. stanovište); 8. stvar 'nekaj' (iz sbh. stvâr); 13. tutòve 'Slovaki' (iz madž. Tót, Tóth 'Slovak'); 14. tъrъpъna 'kad', z napačno branim $t$ - nam. š- (iz tur. şaraphane 'vinska klet').

Sồstuk/sz̀stuk 'slap' (št. 5) ni iz skok, ampak iz korena tok/tek.

V BES niso upoštevani: 4. sm'ồna 'zmečkam' (iz *sb-męti); 6. spaždam se 'združim se', z napačnim $p$ - nam. $n$ - (iz s-naždam 'zvežem se'); 9. stzga 'vrv' $\left(<*^{*}\right.$ sb-tęg-a); 10. stbrna (se) (v kletvi), z izpustom -rtn- > -rn- (iz *sb-trotneti); 11. tij 'to', z nar. vokalom $i$, kakor $\mathrm{v} n i j$ in sij; 12. trbna 'trenem' z izpustom -rpn- >-rn- (iz *tbrp-no-ti); 15. uglùtka 'nerazvit otrok', z disimilacijo - $d l->-g l-($ iz *otzl'udbkъ). 